\title{
Effect of the two tachykinin antagonists, SR 48968 and SR 140333, on cough induced by citric acid in the unanaesthetized guinea-pig
}

\author{
V. Girard*, E. Naline*, P. Vilain**, X. Emonds-Alt**, C. Advenier*
}

\begin{abstract}
Effect of the two tachykinin antagonists, SR 48968 and SR 140333, on cough induced by citric acid in the unanaesthetized guinea-pig. V. Girard, E. Naline, P. Vilain, X. Emonds-Alt, C. Advenier. CERS Journals Ltd 1995.

ABSTRACT: It is now well-established that sensory nerves stimulation in the airway induces bronchoconstriction and inflammation, but also protective reflexes, such as coughing. These effects are mediated through the release of tachykinins (substance $P$ and neurokinin $A$ ) and we have recently shown that $S R$ 48968, a tachykinin $\mathrm{NK}_{2}$-receptor antagonist, inhibited cough induced by citric acid. In this paper, we have studied the effects of SR 48968 administered by aerosol. We have also investigated the effects of $\mathrm{SR}$ 140333, a tachykinin $\mathrm{NK}_{1}$-receptor antagonist, and the combination of both SR 48968 and SR 140333 to determine whether tachykinin $\mathrm{NK}_{1}$ receptors are involved in cough. Finally, we have studied the combined effects of SR 48968 and salbutamol to find out whether the antitussive effect of SR 48968 is a consequence of the inhibition of bronchoconstriction.

Unanaesthetized guinea-pigs were placed in a transparent chamber and exposed to an aerosol of citric acid $(0.4 \mathrm{M})$. The number of coughs was counted by visual inspection and by determination of sounds and pressure variations in the chamber. By the aerosol route, SR 48968 was an efficient antitussive and 16 times more potent than codeine. SR $140333\left(0.1-1 \mathrm{mg}^{-\mathrm{kg}^{-1}}\right.$ i.p.) did not exert any antitussive effect but it potentiated the maximal effect induced by SR 48968. Finally, salbutamol, in a dose $\left(0.3 \mathrm{mg} \cdot \mathrm{kg}^{-1}\right)$ which inhibits bronchoconstriction, but not cough induced by citric acid, did not modify the antitussive effect of SR 48968 .

In conclusion, our results demonstrate that $\mathbf{N K}_{2}$-receptor stimulation plays a predominant role in the regulation of cough reflex, at least in the guinea-pig, as shown

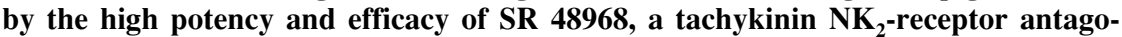

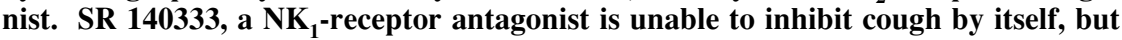
it potentiates SR 48968 in terms of efficiency. Finally, as salbutamol did not modify the effect of SR 48968, it may be suggested that the antitussive effect of SR 48968 is not related to the inhibition of citric acid-induced bronchoconstriction.

Eur Respir J., 1995, 8, 1110-1114.
\end{abstract}

*Laboratoire de Pharmacologie, Faculté de Médecine, Paris, France. **Sanofi Recherche, Montpellier, France.

Correspondence: V. Girard

Laboratoire de Pharmacologie

15 rue de l'Ecole de Médecine

75270 Paris Cedex 06

France

Keywords: Citric acid

cough

guinea-pig

tachykinins

Received: April 291994

Accepted after revision March 41995
Tachykinins, especially substance $\mathrm{P}$ and neurokinin A (NKA), are released from non-myelinated C-fibre endings and play an important role in the physiopathology of airway disease. Substance $\mathrm{P}$ and neurokinin A have been shown to participate in the regulation of airway smooth muscle tone, airway mucus secretion, plasma protein extravasation, cell migration and facilitation of cholinergic neurotransmission [1]. A role for the sensory neuropeptide system has also been proposed in cough [2, $3]$, and KARLSSON [4] has suggested that the most important function of tachykinins in the human respiratory tract is to mediate protective reflexes.

We have demonstrated [5] that SR 48968, a nonpeptide tachykinin $\mathrm{NK}_{2}$ receptor antagonist, inhibited, in a dose-dependent manner, the cough induced by inhalation of an aqueous solution of citric acid in the unanaesthetized guinea-pig, suggesting that tachykinin $\mathrm{NK}_{2}$ receptor stimulation may play an important role in cough. SR
48968, when given intraperitoneally, was approximately 150 times more potent than codeine, and, in contrast to the latter, the effects of SR 48968 were not inhibited by naloxone. UJIIE et al., [6] demonstrated that both FK 888 , an inhibitor of tachykinin $\mathrm{NK}_{1}$ receptors, and FK 224 , an inhibitor of tachykinin $\mathrm{NK}_{1}$ and $\mathrm{NK}_{2}$ receptors, inhibited phosphoramidon-induced cough in the guineapig and concluded, in opposition to us, that substance $\mathrm{P}$ and tachykinin $\mathrm{NK}_{1}$-receptor stimulation was predominant in causing cough.

The aim of this study was to further investigate the role of tachykinin and tachykinin antagonists in cough. Firstly, we investigated the effects of SR 48968 given by aerosol. Secondly, we examined the effects of SR 140333 , a very potent, selective and nonpeptide tachykinin $\mathrm{NK}_{1}$ receptor antagonist [7], and the combination of both SR 140333 and SR 48968 on cough induced by citric acid to determine which tachykinin receptor is involved 
in cough. Finally, since SR 48968 can inhibit the citric acid-induced bronchoconstriction in the guinea-pig [8], we have studied the effects of salbutamol and the combination of both salbutamol and SR 48968 on citric acidinduced cough to determine whether the inhibition of cough is linked to the inhibition of bronchoconstriction.

\section{Materials and methods}

\section{Assay of antitussive activity}

Unanaesthetized, unrestrained, tricoloured Hartley guinea-pigs of both sexes, 250-400 g, were placed individually in a body plethysmograph and exposed to a nebulized aqueous solution of citric acid (0.4M). Exposure to saline caused no respiratory effect. The aerosol was produced by an ultrasonic nebulizer (DeVilbiss, Somerset, PA, USA) and had an aerodynamic mass median diameter of $1.8 \mu \mathrm{m}$ (manufacturer's indications). About 0.3 $\mathrm{ml}$ of the solution was nebulized per minute. The animals were continuously watched by a trained observer, who counted the number of coughs. Coughs were also detected simultaneously by a microphone placed in the chamber and connected to an audio monitor. Occurrence of dyspnoea was not studied in these experiments.

The antitussive effects of SR 48968, codeine, SR 140333, salbutamol and their combinations were assessed following intraperitoneal or aerosol administration. The animals which had intraperitoneal administration were treated $30 \mathrm{~min}$ before challenge with citric acid $0.4 \mathrm{M}$ for $10 \mathrm{~min}$ for SR 140333 and SR 48968, and $5 \mathrm{~min}$ for salbutamol. For the animals which had aerosol administration, citric acid and SR 140333, SR 48968 or codeine were delivered simultaneously by inhalation for $2 \mathrm{~min}$, and the number of coughs was counted over the following $10 \mathrm{~min}$, the guinea-pig being maintained in the body plethysmograph. The citric acid challenge was performed only once for each guinea-pig in separate groups. The animals were not selected.

\section{Drugs}

Drugs used were: codeine $\mathrm{HCl}$, salbutamol sulphate, sodium cromoglycate (Sigma, St Louis, MO, USA); SR 48968 [(S)-N-methyl-[4-(4-acetylamino-4-phenyl piperidino) -2-(3,4-dichlorophenyl)butyl]benzamide], SR 140333 (S)1-(2\{3-\{3,4-dichlorophenyl $\}-1-\{3$-isopropoxyphenylacetyl] piperidin-3yl]ethyl)-4-phenyl-1-azoniabicyclo (2.2.2) (Sanofi Recherche, Montpellier, France); citric acid (Prolabo, Paris, Prance). All drugs were dissolved in 0.9\% saline, except for SR 140333 and SR 48968, which were dissolved in $25 \%$ ethanol and then diluted in saline.

\section{Expression of results and statistical analysis}

Values are given as mean \pm SEM, unless indicated otherwise. The data were analysed first for normal distribution and then for statistical significance by parametric analysis of variance (ANOVA) and post-hoc Bonferroni test, with a p-value of less than 0.05 taken as significant. Data were analysed by a computer using standard statistical packages. When mentioned, a Student's t-test was performed.

\section{Results}

Figure 1 shows that SR 48968 administered by aerosol inhibits cough induced by citric acid. The effective concentration of SR 48968 which inhibited cough by $50 \%$ (EC50) was $0.052 \%$. Under similar conditions, codeine induced a significant inhibition of cough at a concentration of $4 \%$. EC50 was $0.822 \%$. SR 48968 was 16 times more potent that codeine. In terms of molecular weight, the ratio was 32. SR $140333(0.5 \%)$ failed to inhibit the cough induced by citric acid.

Figure 2a shows that, when given by the i.p. route $\left(0.1-1 \mathrm{mg} \cdot \mathrm{kg}^{-1}\right)$, SR 140333 also failed to inhibit cough induced by citric acid, but, when combined with SR 48968 it potentiated significantly $(\mathrm{p}<0.01$, Student's $\mathrm{t}-$ test) the efficiency of the latter (fig. $2 \mathrm{~b}$ ).
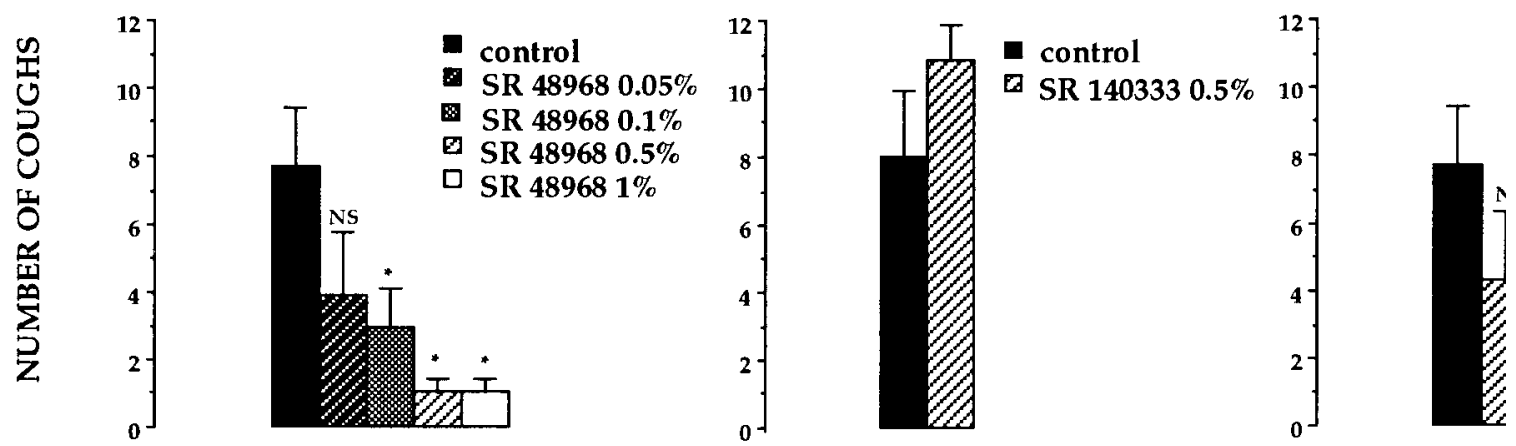

Fig. 1. - Effects of: a) SR 48968; b) SR 140333; and c) codeine administered by aerosol on citric acid-induced cough in unanaesthetized guineapigs. Citric acid and SR 140333, SR 48968 or codeine were delivered simultaneously by inhalation during 2 min, and the number of coughs was counted during the following $10 \mathrm{~min}$, the guinea-pig being maintained in the body plethysmograph. The columns represent the mean \pm sEM of the number of coughs. Significant differences from control values are indicated as, *: p<0.05 using parametric analysis of variance and post-hoc Bonferroni test. Number of animals used for each group was 6-10. $\square$ : control (without pretreatment); $\square$ : SR 48968 $0.05 \%$; $\square$ : SR 48968 0.1\%; $\square$ : SR 48968 0.5\%; $\square$ : SR 48968 1\%; $\square$ : SR 140333 0.5\%; $\square$ : codeine $0.5 \%$; $\square$ : codeine $1 \%$; $\square$ : codeine $2 \%$; $\square$ : codeine $4 \%$. 

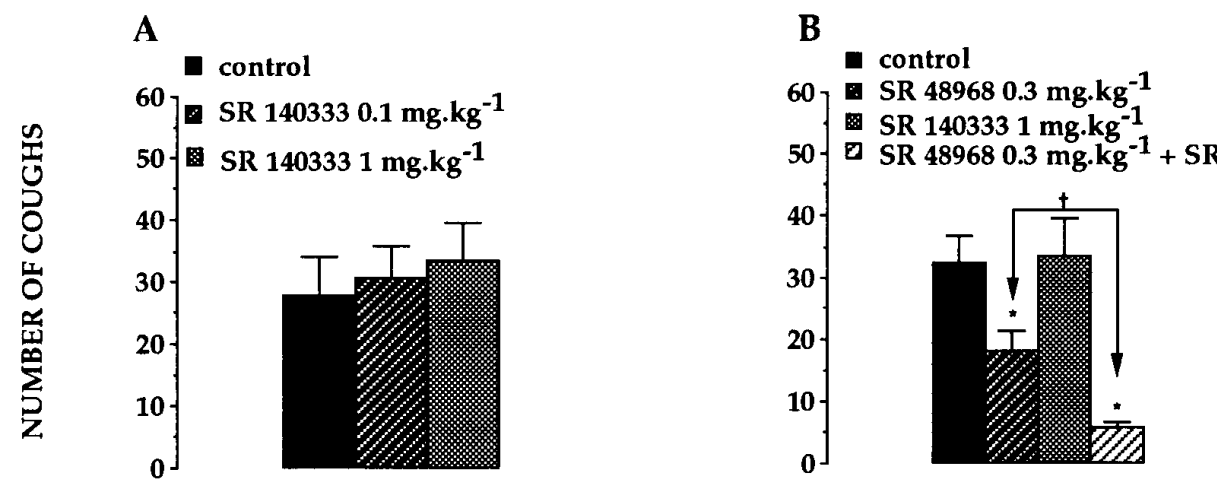

Fig. 2. - Effects of: a) SR $140333\left(0.1-1 \mathrm{mg} \cdot \mathrm{kg}^{-1}\right)$; and b) SR $48968\left(0.3 \mathrm{mg} \cdot \mathrm{kg}^{-1}\right)$ alone or associated with SR $140333\left(1 \mathrm{mg} \cdot \mathrm{kg}^{-1}\right)$ on citric acid-induced cough in unanaesthetized guinea-pigs. The animals were exposed to a nebulized aqueous solution of citric acid $(0.4 \mathrm{M})$ for $10 \mathrm{~min}$. The drugs were administered $30 \mathrm{~min}$ before the citric acid challenge. The columns represent the mean \pm SEM of the number of coughs. Significant differences from control values are indicated as, *: $\mathrm{p}<0.05$ using parametric analysis of variance and post-hoc Bonferroni test. Significant difference from SR 48968 values is indicated as, $\dagger: \mathrm{p}<0.01$ by unpaired two-tailed Student's t-test. Number of animals used for each group was 6-8. $\square$ : control; $\square$ : SR $1403330.1 \mathrm{mg} \cdot \mathrm{kg}^{-1} ; \square:$ : SR $1403331 \mathrm{mg} \cdot \mathrm{kg}^{-1} ; \square:$ : SR $489680.3 \mathrm{mg} \cdot \mathrm{kg}^{-1} ; \square:$ SR $489680.3 \mathrm{mg} \cdot \mathrm{kg}^{-1}+\mathrm{SR}$ $1403331 \mathrm{mg} \cdot \mathrm{kg}^{-1}$

A

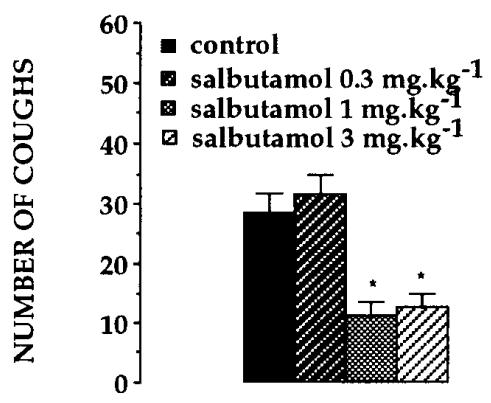

B

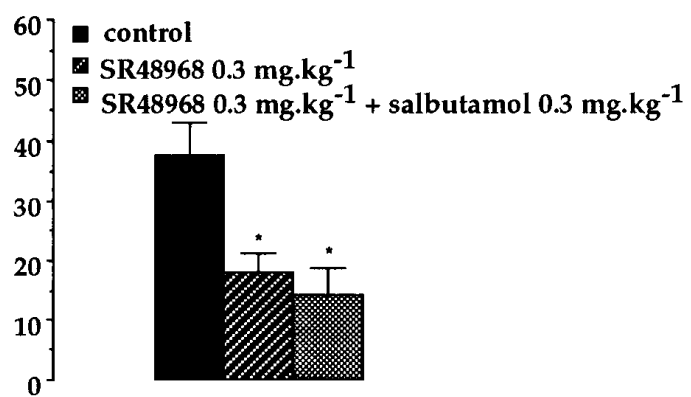

Fig. 3. - Effects of: a) salbutamol $\left(0.3-3 \mathrm{mg} \cdot \mathrm{kg}^{-1}\right)$; and b) SR $48968\left(0.3 \mathrm{mg} \cdot \mathrm{kg}^{-1}\right)$ alone or associated with salbutamol $\left(0.3 \mathrm{mg} \cdot \mathrm{kg}^{-1}\right)$ on citric acid-induced cough in unanaesthetized guinea-pigs. The animals were exposed to a nebulized aqueous solution of citric acid ( $0.4 \mathrm{M})$ for 10 min. SR 48968, SR 140333 were administered $30 \mathrm{~min}$ and salbutamol $5 \mathrm{~min}$ before the citric acid challenge. The columns represent the mean \pm SEM of the number of coughs. Significant differences from control values are indicated as, $*: \mathrm{p}<0.01$ using parametric analysis of variance and post-hoc Bonferroni test. Number of animals used for each group was 5-7. $\square$ : control; $\square: \operatorname{salbutamol~} 0.3 \mathrm{mg} \cdot \mathrm{kg}^{-1}$; $\square: \mathrm{salbutamol} 1 \mathrm{mg} \cdot \mathrm{kg}^{-1}$; $\square$ : salbutamol $3 \mathrm{mg} \cdot \mathrm{kg}^{-1} ; \square$ : SR $489680.3 \mathrm{mg} \cdot \mathrm{kg}^{-1} ; \square$ :SR $489680.3 \mathrm{mg} \cdot \mathrm{kg}^{-1}+\mathrm{salbutamol}^{0} 0.3 \mathrm{mg} \cdot \mathrm{kg}^{-1}$.

Finally, figure $3 \mathrm{a}$ shows that salbutamol $\left(1-3 \mathrm{mg} \cdot \mathrm{kg}^{-1}\right.$ i.p.) could inhibit cough induced by citric acid and, in a subefficient dose $\left(0.3 \mathrm{mg} \cdot \mathrm{kg}^{-1}\right)$, did not modify the effect of SR 48968 (fig. 3b).

\section{Discussion}

Reflex cough is usually considered to be mediated by irritant receptors with myelinated afferents in the larynx and slowly or rapidly adapting stretch receptors in the tracheobronchial tree [3], but it has recently been found that $\mathrm{C}$-fibre endings may also be involved in reflex cough.
Thus, inhaled capsaicin, predominantly a C-fibre ending stimulant, causes cough in man and in guinea-pig [9-11]. Inhalation of a citric acid aqueous solution is known to cause cough in guinea-pig and man, and this response seems to involve sensory mechanisms, since it is inhibited in the guinea-pig by pretreatment with high concentrations of capsaicin which causes degeneration of sensory nerves $[2,3]$. Citric acid can also induce dyspnoea, and may depend on chemosensitive C-fibres afferents since it was observed in capsaicin pretreated animals [10]. Nevertheless, this pretreatment did not affect the dyspnoea caused by administration of exogenous NKA 
or neurokinin $\mathrm{B}$ (NKB) [12]. Involvement of sensory neuropeptides in reflex cough has also been demonstrated by KoHrogi $e t$ al. [13], TAKAHAMA et al. [14] and UJIIE et al. [6], who showed that substance P [13], NKA [14], and phosphoramidon [6] induced cough in the guineapig. However, a direct tussigenic effect of substance $P$ or NKA has not yet been demonstrated in man [15]. Finally and interestingly, to demonstrate that tachykinins play a role in cough, HATHAWAY et al. [16] have reported that, in heart-lung transplant patients, inhaled capsaicin was unassociated with coughing, whereas all normal and asthmatic subjects they tested coughed with capsaicin.

A new method of studying the role played by tachykinins in the mechanism of citric acid- or phosphoramidoninduced cough is to use antagonists of neurokinins. SR 48968, a tachykinin $\mathrm{NK}_{2}$ receptor antagonist [17, 18] administered intraperitoneally is a potent antagonist of citric acid-induced [5], or capsaicin-induced [19] cough. Similarly, the long-acting peptide tachykinin antagonist MEN 10627 has been shown to inhibit cough and bronchoconstriction induced by inhalation of ovalbumin in sensitized guinea-pigs [20]. UJIIE et al. [6] have shown that FK 224, an antagonist both of $\mathrm{NK}_{1}$ and $\mathrm{NK}_{2}$ receptors, and FK 888, an antagonist of $\mathrm{NK}_{1}$ receptors, inhibit cough induced by phosphoramidon, tobacco smoke or substance P, whereas, FAHY et al. [21] failed to observe an effect of CP-99,994, an antagonist of $\mathrm{NK}_{1}$ receptor, on cough induced by inhalation of saline of increasing osmolarity in asthmatic patients.

In the present study, we have shown, in addition to our previous study [5], that SR 48968 is also active when administered as aerosol; but when this route was used, the difference in potency with codeine seemed to be slightly smaller than the one we observed when the compounds were given intraperitoneally, where SR 48968 was found to be 150 times more potent than codeine [5].

The second purpose of this work was to further investigate the type of receptor involved in the link between tachykinins and cough. We have shown that SR 140333, a very potent nonpeptide antagonist of $\mathrm{NK}_{1}$ receptor [7] has no antagonistic effect on citric acid-induced cough when given by aerosol or by the intraperitoneal route, but is able to potentiate the protective effect of SR 48968 . When both drugs were given by the i.p. route, the potentiation actually concerned the efficiency of SR 48968. We have previously shown [5] that the maximum effect of SR 48968 was observed in doses of $0.3 \mathrm{mg} \cdot \mathrm{kg}^{-1}$, that its inhibition of the citric acid effects was in the order of $61 \%$, and that its maximum effect was similar to that of codeine. In the present study, we showed that the SR 140333 and SR 48968 association exerted on the citric acid effect a significantly superior maximum inhibitory effect (about 82\%), and that in terms of efficiency it was superior to codeine. Such a potentiation is difficult to explain, but it has already been observed in other experimental models, such as the inhibition of the bronchoconstriction induced by intravenous SP, NKA, capsaicin or resiniferatoxin in the guinea-pigs [22-24], or by inhalation of ovalbumin in sensitized animals [25].

Our results on the lack of effect of SR 140333 on cough induced by citric acid in the guinea-pig are in agreement with the results obtained in asthmatic patients by FAHY et al. [21], who have shown that the $\mathrm{NK}_{1}$ receptor antagonist CP-99,994, did not inhibit bronchoconstriction and cough induced by inhalation of aerosols of increasing osmolarity. Our results, however, are in conflict with those of UJIIE et al. [6], who showed that FK 888 , an antagonist of $\mathrm{NK}_{1}$ receptors, inhibits the cough induced by intraperitoneal phosphoramidon and by cigarette smoke. It must be noted that FK 888 has significant effects on citric acid-induced cough only when it is given in concentrations of at least $10^{-7} \mathrm{M}$, and that $10^{-5}$ $\mathrm{M}$ is necessary to inhibit cigarette smoke-induced cough. Such concentrations seem to be high in view of the potency of the $\mathrm{NK}_{1}$ antagonistic effect since a $\mathrm{pA}_{2}$ (the negative logarithm of the molar concentration of antagonist in the presence of which the potency of the agonist is reduced by 2 times) of 9.29 has been reported in the guinea-pig ileum in vitro [26]. Data concerning the $\mathrm{NK}_{2}$ effect of FK 888 are rare, and the only functional evaluation of FK 888 activity on $\mathrm{NK}_{2}$ receptors has been carried out in vitro on rat vas deferens (concentration producing 50\% inhibition (IC50) $=11 \mu \mathrm{M}$ ) [26]. In the study by UJIIE et al. [6], in the absence of in vivo experiments aimed at evaluating the $\mathrm{NK}_{2}$ activity in the guineapig, notably with FK 888 given as aerosol, a component of $\mathrm{NK}_{2}$ receptor antagonists cannot be excluded in the effects of FK 888, which might act alone or associated with the $\mathrm{NK}_{1}$ blocker effect.

Our third purpose in this work was to determine whether inhibition of citric acid-induced cough was related to citric acid-induced bronchoconstriction. SATOH et al. [8], found that, in the guinea-pig, SR 48968 inhibited the bronchoconstriction induced by citric acid in doses similar to those that we had observed for the inhibition of cough. Dissociation between cough and bronchoconstriction has clearly been demonstrated by FORSBERG et al. [27] who, in agreement with FULLER and COLLIER [28] and JACKSON [29], showed that sodium cromoglycate inhibited bronchoconstriction but not citric acid-induced cough, whereas lidocaine inhibited cough but not bronchoconstriction. In this paper, we have shown that salbutamol exerted an antitussive effect in doses of $1-3 \mathrm{mg} \cdot \mathrm{kg}^{-1}$, i.e. doses that were considerably higher than those which exerted bronchodilator effects in the guinea-pig. The effective dose producing 50\% inhibition (ED50) of the bronchodilator effect of salbutamol versus histamine is $0.6 \mu \mathrm{g} \cdot \mathrm{kg}^{-1}$ [30]. Consequently, we have pretreated animals with salbutamol at a dose $\left(0.3 \mathrm{mg} \cdot \mathrm{kg}^{-1}\right)$ which is not antitussive, but presents marked bronchodilator effects. Under these conditions, SR 48968 was still efficient against cough induced by citric acid. These data enable us to conclude that SR 48968 probably exerts its antitussive effect independently of its antagonistic effect on bronchoconstriction and, therefore, is capable, unlike sodium cromoglycate, salbutamol or lidocaine, of inhibiting simultaneously and within the same dose-range cough as well as bronchoconstriction

In conclusion, our results demonstrate the absence of antitussive effect of the $\mathrm{NK}_{1}$-receptor antagonist, SR 140333 , when given alone, but that this drug can potentiate the effects of the $\mathrm{NK}_{2}$ antagonist SR 48968. This 
suggests that $\mathrm{NK}_{2}$-receptor stimulation might play a predominant role in the regulation of reflex cough, at least in the guinea-pig, and that $\mathrm{NK}_{2}$ tachykinin antagonists or their combination with $\mathrm{NK}_{1}$ receptor antagonists might be of interest for the treatment of cough or of the "sensory hyperresponsiveness" suggested by GARLAND and ADCOCK [31] and KARLSSON [4]. Furthermore, since salbutamol at doses which inhibit bronchoconstriction did not modify the antitussive effect of SR 48968, it may be suggested that the antitussive effect of SR 48968 is unrelated to the inhibition of citric acid-induced bronchoconstriction.

\section{References}

1. Barnes PJ, Baraniuk J, Belvisi MG. Neuropeptides in the respiratory tract. Am Rev Respir Dis 1991; 144: 1187-1198 (Part I) and 1391-1399 (Part II).

2. Forsberg K, Karlsson JA, Theodorsson E, Lundberg JM, Persson CGA. Cough and bronchoconstriction mediated by capsaicin-sensitive sensory neurons in the guineapig. Pulm Pharmacol 1988; 1: 33-39.

3. Karlsson JA, Sant'Ambrogio G, Widdicombe J. Afferent neural pathways in cough and reflex bronchoconstriction. J Appl Physiol 1988; 65: 1007-1023.

4. Karlsson JA. A role for capsaicin sensitive, tachykinin containing nerves in chronic coughing and sneezing but not in asthma: a hypothesis. Thorax 1993; 48: 396-400.

5. Advenier C, Girard V, Naline E, Vilain P, Emonds-Alt X. Antitussive effect of SR 48968, a non-peptide tachykinin $\mathrm{NK}_{2}$ receptor antagonist. Eur J Pharmacol 1993; 250: $169-171$.

6. Ujiie Y, Sekizawa K, Aikawa T, Sasaki H. Evidence for substance $\mathrm{P}$ as an endogenous substance causing cough in guinea-pigs. Am Rev Resp Dis 1993; 148: 1628-1632.

7. Emonds-Alt X, Doutremepuich JD, Heaulme M, et al. In vitro and in vivo biological activities of SR 140333, a novel potent nonpeptide tachykinin $\mathrm{NK}_{1}$ receptor antagonist. Eur J Pharmacol 1993; 250: 403-413.

8. Satoh H, Lou YP, Lee LY, Lundberg JM. Inhibitory effects of capsazepine and the $\mathrm{NK}_{2}$ antagonist SR 48968 on bronchoconstriction evoked by sensory nerve stimulation in guinea-pigs. Acta Physiol Scand 1992; 146: 535-536.

9. Collier JG, Fuller RW. Capsaicin inhalation in man and the effect of sodium cromoglycate. Br J Pharmacol 1984; 81: 113-118.

10. Forsberg K, Karlsson JA. Cough induced by stimulation of capsaicin-sensitive sensory neurons in conscious guinea-pig. Acta Physiol Scand 1986; 128: 319-320.

11. Laude EA, Higgins KS, Morice AH. A comparative study of the effects of citric acid, capsaicin and resiniferatoxin on the cough challenge in guinea-pig and man. Pulm Pharmacol 1993; 6: 171-175.

12. Kusner EJ, Buckner CK, DeHaas CJ, Lengel DJ, Marks RL, Krell RD. Tachykinin-induced dyspnoea in conscious guinea-pigs. Eur J Pharmacol 1992; 210: 299-306.

13. Kohrogi H, Graf PD, Sekizawa K, Borson DB, Nadel JA. Neutral endopeptidase inhibitors potentiate substance $\mathrm{P}$ and capsaicin-induced cough in awake guinea-pigs. $J$ Clin Invest 1988; 82: 2063-2068.

14. Takahama K, Fuchikami J, Isohama Y, Kai H, Miyata T. Neurokinin A, but not neurokinin B and substance
$\mathrm{P}$, induces codeine-resistant coughs in awake guinea-pigs. Regul Pept 1993; 46: 236-237.

15. Joos G, Pauwels R, Van Der Straeten M. Effect of inhalated substance $\mathrm{P}$ and neurokinin A on the airways of normal and asthmatic subjects. Thorax 1987; 42: 779-783.

16. Hathaway TJ, Higenbottam TW, Morrison JFJ, Clelland CA, Wallwork J. Effects of inhalated capsaicin in heartlung transplant patients and asthmatic subjects. Am Rev Respir Dis 1993; 148: 1233-1237.

17. Emonds-Alt X, Vilain P, Goulaouic P, et al. A potent and selective nonpeptide antagonist of the neurokinin $\mathrm{A}$ $\left(\mathrm{NK}_{2}\right)$ receptor. Life Sci 1992; 50: 101-106.

18. Advenier C, Rouissi N, Nguyen QT, et al. Neurokinin A $\left(\mathrm{NK}_{2}\right)$ receptor revisited with SR 48968, a potent nonpeptide antagonist. Biochem Biophys Res Commun 1992; 184: 1418-1424.

19. Robineau P, Petit C, Staczek J, Peglion JL, Brion JD, Canet E. $\mathrm{NK}_{1}$ and $\mathrm{NK}_{2}$ receptors involvement in capsaicin-induced cough in guinea-pigs. Am J Respir Crit Care Med 1994; 149(4): A186.

20. Evangelista S, Ballati J, Perretti F. MEN 10,627, a new selective $\mathrm{NK}_{2}$ receptor antagonist inhibits antigen-induced bronchoconstriction in sensitized guinea-pigs. Neuropeptides 1994; 26(Suppl. 1): 39-40.

21. Fahy JV, Wong HH, Geppetti P, Nadel JA, Boushey HA. Effect of an $\mathrm{NK}_{1}$ receptor antagonist $(\mathrm{CP}-99,994)$ on hypertonic saline-induced bronchoconstriction and cough in asthmatic subjects. Am J Respir Crit Care Med 1994; 149(4): A1057.

22. Foulon DM, Champion E, Masson P, Rodger IW, Jones TR. $\mathrm{NK}_{1}$ and $\mathrm{NK}_{2}$ receptors mediate tachykinin and resiniferatoxin-induced bronchospasm in guinea-pigs. $\mathrm{Am}$ Rev Respir Dis 1993; 148: 915-921.

23. Buckner CK, Liberati N, Dea D, et al. Differential blockade by tachykinin $\mathrm{NK}_{1}$ and $\mathrm{NK}_{2}$ receptor antagonists of bronchoconstriction induced by direct-acting agonists and the indirect-acting mimetics capsaicin, serotonin and 2methyl-serotonin in the anaesthetized guinea-pig. $J$ Pharmacol Exp Ther 1993; 267(3): 1168-1175.

24. Bertrand C, Nadel JA, Graf PA, Geppetti P. Capsaicin increases airflow resistance in guinea-pigs in vivo by activating both $\mathrm{NK}_{2}$ and $\mathrm{NK}_{1}$ tachykinin receptors. Am Rev Respir Dis 1993; 148: 909-914.

25. Bertrand C, Geppetti P, Graf PA, Foresi A, Nadel JA. Involvement of neurogenic inflammation in antigeninduced bronchoconstriction in guinea-pigs. Am J Physiol 1993; 265 (Lung Cell Mol Physiol 9): L507-L511.

26. Fujii T, Murai M, Morimoto H, et al. Pharmacological profile of a high affinity dipeptide $\mathrm{NK}_{1}$ receptor antagonist, FK888. Br J Pharmacol 1992; 107: 785-789.

27. Forsberg K, Karlsson JA, Zackrisson C, Persson CGA. Selective inhibition of cough and bronchoconstriction in conscious guinea-pig. Respiration 1992; 59: 72-76.

28. Fuller RW, Collier JC. Sodium cromoglycate and atropine block the fall in FEV1 but not the cough induced by hypotonic mist. Thorax 1984; 39: 766-770.

29. Jackson DM. The effect of nedocromil sodium, sodium cromoglycate and codeine phosphate on citric acid-induced cough in dogs. Br J Pharmacol 1988; 93: 609-612.

30. Advenier C, Qian Y, Law Koune JD, Molimard M, Candenas ML Naline E. Formoterol and salbutamol inhibit bradykininand histamine-induced airway microvascular leakage in guinea-pig. Br J Pharmacol 1992; 105: 792-798.

31. Garland LG, Adcock JJ. New approches to the attenuation of sensory reflexes in airway inflammation. New Drugs For Asthma Therapy, In: Anderson GP, Chapman ID, Morley J, eds. 1991; AAS 34: pp. 497-517. 